\title{
Records of breeding in Wilson's Plover Charadrius wilsonia with new localities for Brazil
}

\section{P. Andrade A,b (D) R. M. Lyra-Neves $^{a, b}$ (D) H. M. L.S. Andrade Ad $^{a, b}$ U. P. Albuquerque (D), $^{a}$, A. J.'S. Siqueirac (D), A. Guzzic (D) and W. R. Telino-Júnior ${ }^{a, b *}$ (D)}

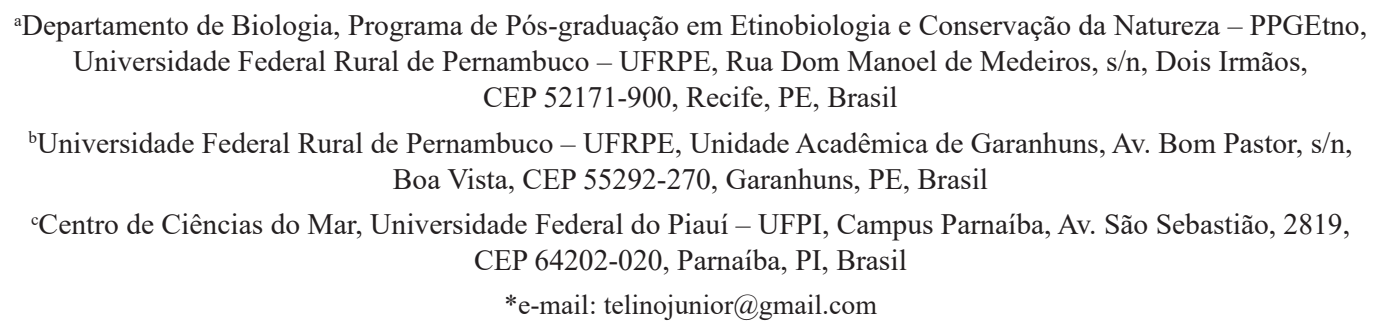

Received: February 05, 2018 - Accepted: May 30, 2018 - Distributed: February 28, 2020

(With 4 figures)

\begin{abstract}
Wilson's Plover, Charadrius wilsonia, is widely distributed in coastal areas of the Americas. This report presents the first record of breeding in this species on Coroa do Avião Island, on the coast of Pernambuco, and in the estuary of the Cardoso and Camurupim rivers, on the coast of Piauí, in northeastern Brazil, extending the known area of reproduction of this species in this region. One breeding pair was observed on October 29th 2014 on Coroa do Avião Island, and a second pair was recorded on April 6th 2016 in the Cardoso/Camurupim estuary on the Piauí coast. Both the male and the female contributed to the incubation of the eggs. The nest on Coroa do Avião island was camouflaged by the local vegetation, but despite this, the eggs were attacked by a predator. Possible predators observed on the island included Caracara plancus and domestic cats and dogs.
\end{abstract}

Keywords: shorebird conservation, Coroa do Avião Island, Cardoso and Camurupim Estuary, Charadriiformes, reproduction.

\section{Registros da reprodução de Charadrius wilsonia, com novas ocorrências para o Brasil}

\section{Resumo}

Charadrius wilsonia (Wilson's Plover) está amplamente distribuído pela costa das Américas. Este é o primeiro registro de reprodução no litoral de Pernambuco, Coroa do Avião, e no estuário dos rios Cardoso e Camurupim, litoral do Piauí, Brasil, ampliando a área de reprodução no Nordeste do Brasil. Foi encontrado um casal em período reprodutivo em 23 de outubro de 2014 na ilha Coroa do Avião, litoral de Pernambuco e outro registro em 06 de abril de 2016 nos estuários Cardoso e Camurupim, litoral do Piauí. Foi observado que o macho e a fêmea contribuem na incubação dos ovos. A vegetação na ilha contribui para a camuflagem do ninho, bem como na proteção dos ovos pelos predadores. Apesar da proteção ocorreu a predação do ninho na ilha Coroa do Avião. Alguns possíveis predadores foram registrados na ilha, como Caracara plancus que diariamente frequentam a área e animais domésticos como cães e gatos.

Palavras-chave: conservação de aves limícolas, Ilha Coroa do Avião, Estuário dos Rios Cardoso e Camurupim, Charadriiformes, reprodução.

\section{Introduction}

Wilson's Plover, Charadrius wilsonia (Ord, 1814), is a shorebird of the family Charadriidae, which is usually found in coastal environments. Five subspecies have been described (Grantsau and Lima, 2008), although most authors recognize only three $-C$. $w$. wilsonia, which is found in the eastern United States, eastern Mexico, the Bahamas, Greater Antilles, northern Lesser Antilles, and southern and eastern Brazil; C. w. beldingi (Ridgway, 1919), found on the Pacific coast from Baja California to Panama, Ecuador, and Peru, and C. w. cinnamominus (Ridgway, 1919), which is distributed between Colombia and French Guiana, the Netherlands Antilles, the islands of Venezuela, Trinidad, Grenada and Mustique (Caio et al., 2011). 
Grantsau and Lima (2008) described a new subspecies, Charadrius wilsonia brasiliensis, which is known to breed on the coasts of northern and eastern Brazil between Maranhão and Bahia, with records of occurrence from the Brazilian states of Pará, Amapá, Maranhão, Piauí, Ceará, Rio Grande do Norte, Pernambuco, Alagoas, Bahia and São Paulo (Telino Júnior et al., 2003; Azevedo Júnior et al., 2004; Cabral et al., 2006; Grantsau and Lima, 2008; Lunardi and Macedo, 2010). The species appears to be monogamous with the male being involved in the incubation of the eggs (Bergstrom, 1981a).

Coastal beaches are essential to the reproductive success of a number of threatened species, although the ongoing development of coastal areas and the recreational use of beaches have been impacting the reproductive success of the species found in these environments (Flemming et al., 1988; Burger, 1994; Weston and Elgar, 2007). Wilson's Plover is a prime example, and the species is classified as vulnerable in the Brazilian list of endangered species (DOU, 2014).

The decline of C. wilsonia populations, and the small number of individuals found in most areas may be related to human disturbance and the loss of the environments used by these birds (Brown et al., 2001; Boettcher et al., 2007). The birds typically nest in marine coastal areas with sparse vegetation, in dunes, sandbanks, lagoon margins, and beaches above the high tide line. However, few data are available on the breeding patterns in the $C$. wilsonia populations of the southern hemisphere (Corbat and Bergstrom, 2000; Grantsau and Lima, 2008; Lunardi and Macedo, 2010).

The present study documents the reproduction of C. wilsonia at two sites in northeastern Brazil, Coroa do Avião Island, on the coast of Pernambuco, and the estuary of the Cardoso and Camurupim rivers, located on the coast of the state of Piauí. These observations represent the first records of $C$. wilsonia breeding in both Pernambuco and Piauí, and highlights the threats to the species in these regions.

\section{Material and Methods}

\subsection{Study area}

Coroa do Avião Island is located on the southern bar of the Santa Cruz Channel in Igarassu, Pernambuco, Brazil $\left(7^{\circ} 40^{\prime} \mathrm{S}, 34^{\circ} 50^{\prime} \mathrm{W}\right)$. This area is known to be an important overwintering site for migratory birds in northeastern Brazil. The island is a sandbank formed by sediments from the Santa Cruz Channel. It is covered with grasses, as well as having exotic plants such as coconut (Cocos nucifera L.) and Indian almond (Terminalia catappa $\mathrm{L}$.) in its central portion. The higher ground in the east of the island is dominated by the beach bean, Canavalia rosea Sw. (Fabaceae), and the goat's foot, Ipomoea pes-caprae (L.) R. Brown (Convolvulaceae), with the swampy low-lying areas being covered with phanerogams.

Local artisanal fishers harvest mollusks along the shore of the island, and there is considerable tourism infrastructure, including bars and restaurants, and boating facilities (Macedo et al., 2000; Azevedo Júnior et al., 2001; Azevedo Júnior et al., 2002). The local climate is characterized by a dry season in the austral summer, between September and February, and a rainy season between March and August (Eskinazi-Leça et al., 1980). The external morphology of the plovers observed on Coroa do Avião Island was consistent with that of $C$. w. brasiliensis, as described by Grantsau and Lima (2008) and Lunardi and Macedo (2010).

The estuary of the Cardoso and Camurupim rivers is

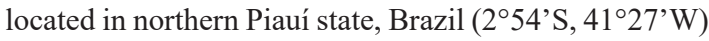
(Figure 1). The area is an important resting and feeding point for several species of wading birds, including Charadrius wilsonia. The climate of the region is characterized by two well-defined seasons, a rainy season between January and May, and a dry season from July to December (Rocha, 2016).

\section{Results}

\subsection{Observations of reproductive behavior, nests and eggs}

The first evidence of breeding in C. wilsonia brasiliensis was obtained when a pair was encountered foraging in the intertidal zone of Coroa do Avião Island on October 23rd 2014. These birds engaged in a broken-wing display (Figure 2a and 2b), in an attempt to distract the observers from the site of their nest (Figure $3 a$ and $3 b$ ), which was located on the upper beach, and partially hidden by the vegetation. The nest was formed by a small depression in the ground with some dry twigs, and camouflaged by beach bean (Canavalia rosea (Sw.) and goat's foot (Ipomoea pes-caprae (L.) R. Brown). The nest containing three eggs, which measured $34.8 \mathrm{~mm}, 34.7 \mathrm{~mm}$ and $34.4 \mathrm{~mm}$ (length) and $25.3 \mathrm{~mm}, 25.1 \mathrm{~mm}$ and $24.7 \mathrm{~mm}$ (width), respectively. It was not possible to weigh the eggs.

The eggs were light beige in color, with dark brown spots over the whole of their surface, but slightly more concentrated on their basal portion. During the course of the day, the two plovers were observed taking turns to incubate the eggs. During two years of surveys on the island, only two pairs of $C$. wilsonia were observed, and only one of these was breeding. The area was visited again after 15 days, although the nest could not be found, and there was no sign of the nestlings, although the adult pair was observed.

At the Cardoso and Camurupim estuary, a nest was found on April 6th 2016. This nest was also formed by a small depression in the soil, located in an area completely devoid of vegetation, and was composed only of sticks and small pieces of shells (Figure 4a). This nest also had three eggs, although measurements were not obtained. This nest was monitored throughout the rest of the incubation period, from early April, to early May, when all three eggs hatched (Figure $4 \mathrm{a}$ and $4 \mathrm{~b}$ ). Several individuals were observed in the breeding area, but only one couple was observed at the nest site. The area is a breeding ground for other birds, such as Sternula antillarum and Haematopus palliatus. 
$50^{\circ} \mathrm{O}^{\prime} \mathrm{W} \quad 48^{\circ} \mathrm{O}^{\prime} \mathrm{W} \quad 46^{\circ} \mathrm{O}^{\prime} \mathrm{W} \quad 44^{\circ} \mathrm{O}^{\prime} \mathrm{W} \quad 42^{\circ} \mathrm{O}^{\prime} \mathrm{W} \quad 40^{\circ} \mathrm{O}^{\prime} \mathrm{W} \quad 38^{\circ} \mathrm{O}^{\prime} \mathrm{W} \quad 36^{\circ} \mathrm{O}^{\prime} \mathrm{W} \quad 34^{\circ} \mathrm{O}^{\prime} \mathrm{W} \quad 32^{\circ} \mathrm{O}^{\prime} \mathrm{W}$
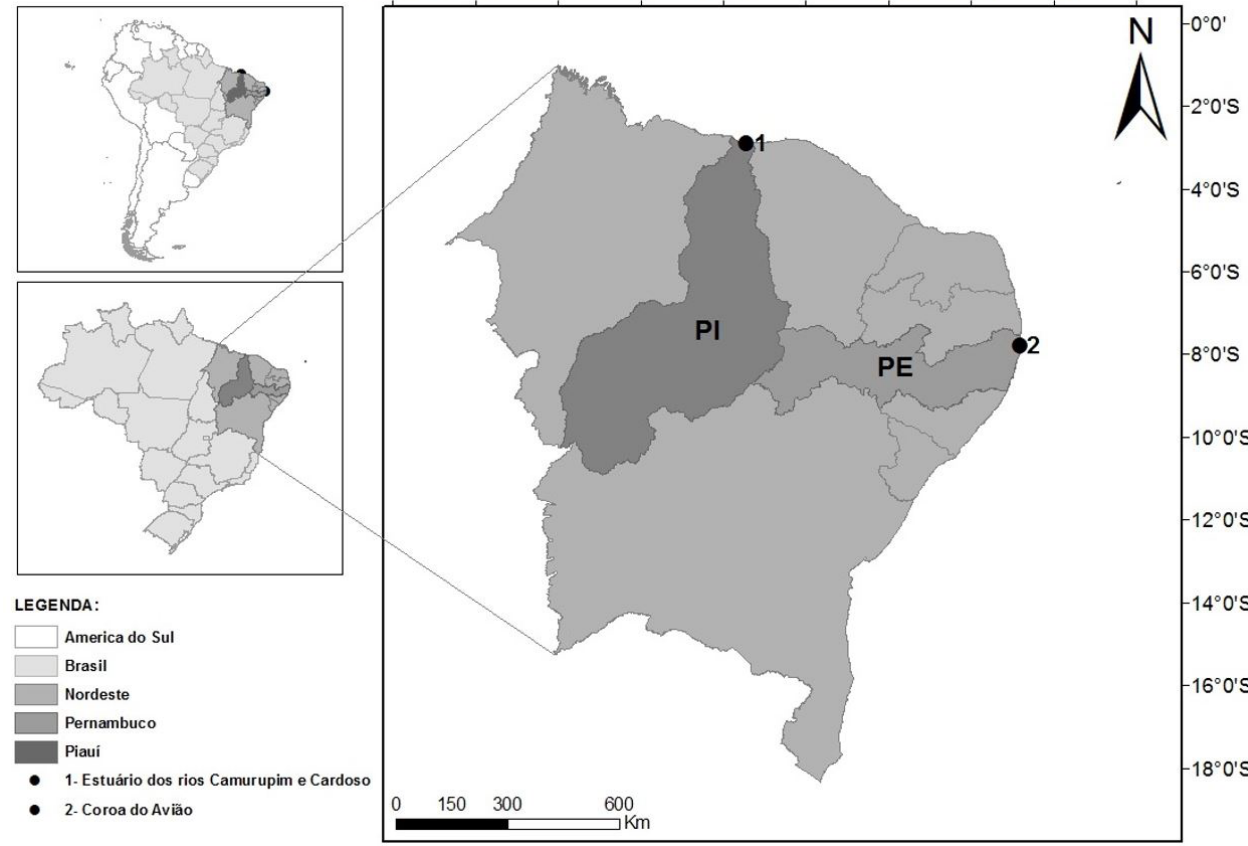

Figure 1. Location of the study sites in Brazil: (1) the Cardoso and Camurupim estuary (Piauí), and (2) Coroa do Avião Island, Pernambuco.
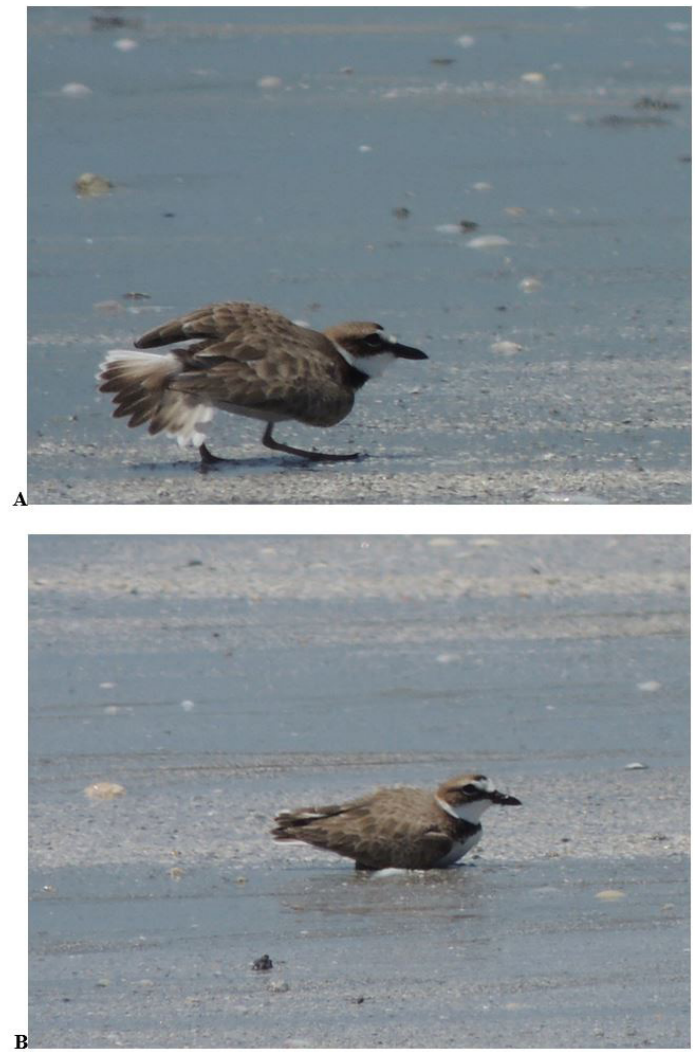

Figure 2. Broken-wing display in Charadrius wilsonia on Coroa do Avião Island, Igarassu, Brazil. Photographs by Wallace Rodrigues Telino Júnior.
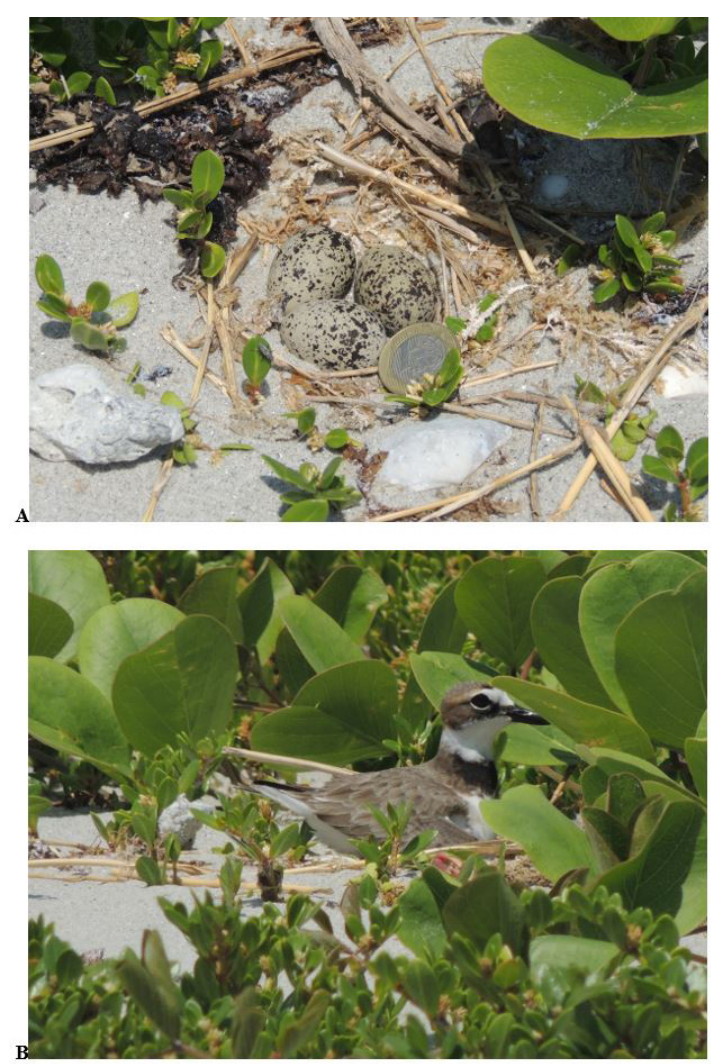

Figure 3. Nest of Charadrius wilsonia and brooding male on Coroa do Avião Island, Igarassu, Brazil. Photographs by Wallace Rodrigues Telino Júnior. 

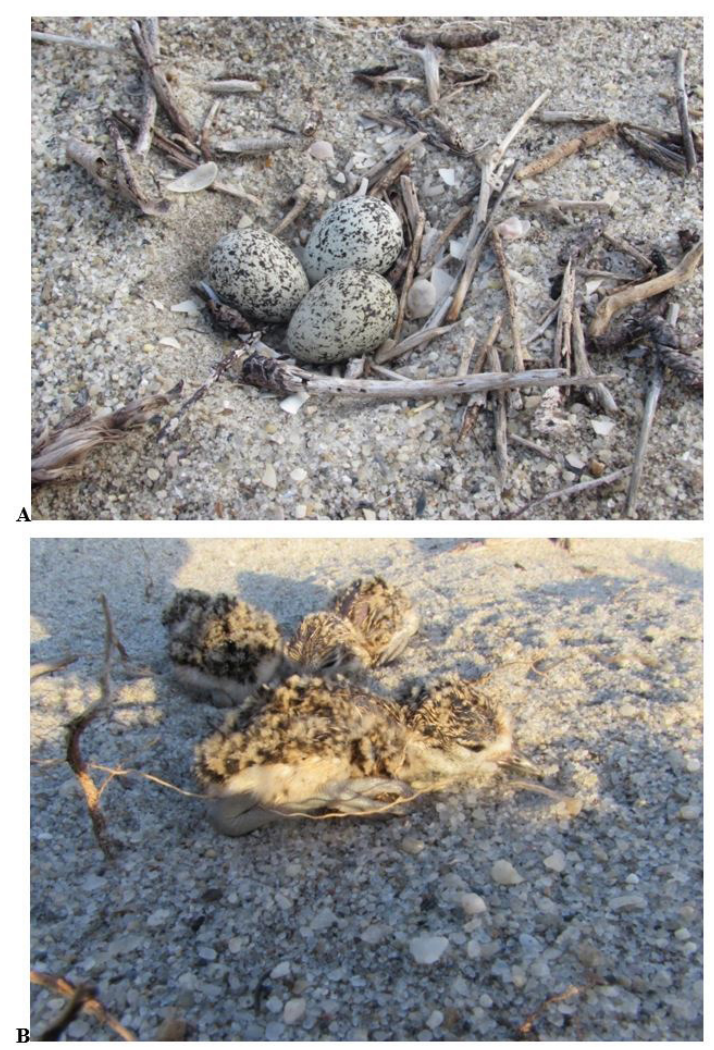

Figure 4. Nest of Charadrius wilsonia and chicks in the estuary of the Camurupim and Cardoso rivers, Cajueiro da Praia, Brazil. Photographs by Airton Siqueira.

\section{Discussion}

This study presents the first reproductive records of C. wilsonia at Coroa do Avião Island in Pernambuco and in the Cardoso and Camurupim estuary in Piauí. The first records of breeding in this species in northeastern Brazil were obtained from the mouth of the São Francisco River $\left(10^{\circ} 30^{\prime} \mathrm{S}, 36^{\circ} 24^{\prime} \mathrm{W}\right)$ in Alagoas, in 1991, and Maiau Island $\left(1^{\circ} 18^{\prime} \mathrm{S}, 4^{\circ} 57^{\prime} \mathrm{W}\right.$ ) in Maranhão, in 1992 (Shultz Neto et al., 1992). Subsequently, Rodrigues et al. (1996) observed breeding plovers on Cajual ( $\left.2^{\circ} 28^{\prime} \mathrm{S}, 44^{\circ} 30^{\prime} \mathrm{W}\right)$ and Cururupu ( $\left.2^{\circ} 24^{\prime} \mathrm{S}, 44^{\circ} 04^{\prime} \mathrm{W}\right)$ islands in Poço Lumiar, Maranhão. During a study of shorebirds at the Diamante Branco salt evaporation plant on the coast of Rio Grande do Norte ( $\left.5^{\circ} 05^{\prime} \mathrm{S}, 36^{\circ} 16^{\prime} \mathrm{W}\right)$, Azevedo Júnior et al. (2004) found a C. wilsonia chick, in March 1999, and a nest with three eggs (one of which was destroyed) in June 2000. Grantsau and Lima (2008) recorded the species breeding at Mangue Seco ( $\left.12^{\circ} 40^{\prime} \mathrm{S} 38^{\circ} 10^{\prime} \mathrm{W}\right)$, on the northern coast of Bahia, while Lunardi and Macedo (2010) observed C. wilsonia breeding $230 \mathrm{~km}$ further south in Todos os Santos Bay $\left(12^{\circ} 44^{\prime} \mathrm{S}, 38^{\circ} 45^{\prime} \mathrm{W}\right)$, the southernmost record from the Brazilian coast.

The plumage of the male and female plovers observed during the present study was consistent with the pattern observed by Grantsau and Lima (2008) and Lunardi and
Macedo (2010), indicating that the animals were members of the subspecies, C. w. brasiliensis.

The defensive display used by the Coroa do Avião parents to protect its nest was similar to that described by Wierma (1996) and Bergstrom (1988c), and this behavior provides a useful clue, together with the breeding plumage, to the timing of the breeding period in these birds. The nest may be protected by the adjacent vegetation, and in particular by other objects, such as stones and even cattle dung, as observed by Bergstrom (1988a, b), who concluded that these objects may function primarily as a wind barrier. Lunardi and Macedo (2010) also observed vegetation and objects apparently being used to protect the nest from easterly and southeasterly winds, which are predominant in August on the coast of northeastern Brazil. The nest on Coroa do Avião Island was built on the western side of the island, which would be relatively well-protected from easterly winds, while the Cardoso and Camurupim nest was found in the north of the estuary, where winds are strongest between October and December, with mean velocities ranging from 4.00 to $5.81 \mathrm{~m} / \mathrm{s}$, and weakest between April and July, when speeds oscillates between $1.76 \mathrm{~m} / \mathrm{s}$ and $3.4 \mathrm{~m} / \mathrm{s}$. Vegetation may also contribute to the camouflage of the nest from the view of potential predators, as observed by Shultz Neto et al. (1992), in the case of predation by Mivalgo chimachima.

The eggs were similar in number, size, and coloration to the clutches described previously for the species (Rodrigues et al., 1996; Zdravkovic et al., 2018; Grantsau and Lima, 2008; Lunardi and Macedo, 2010; Brown and Snyder III, 2013). Predation was the mostly likely cause of the disappearance of the nest at Coroa do Avião, although the lack of remains provides no tangible clues. One possibility is the presence on the island of domestic animals, such as cats and dogs, associated with the many local commercial establishments. Dogs taken to beaches by tourists or fishermen are potential threats to breeding C. wilsonia (Diniz et al. 2016). Natural predators include Caracara plancus, with up to four individuals being observed foraging on Coroa do Avião island during visits, although the accidental destruction of the nest by fishers or tourists, or their dogs, cannot be ruled out completely. While the nest at Cardoso and Camurupim was not attacked, a number of threats were observed, with motor vehicles and domestic dogs being the main threats observed in the area.

The results of the present study reinforce the conclusion that $C$. wilsonia is able to breed in northeastern Brazil, in both Pernambuco and Piauí, although anthropogenic pressures are clear in both cases, including the presence of domestic (cats and dogs) and synathropic (rats) animals that may prey on eggs and nestlings. Non-sustainable tourism may also restrict the reproductive potential of the species in these areas. These findings highlight the urgent need for measures to mitigate these unsustainable or predatory activities that have a negative impact on the biological cycle of these birds. This would guarantee the conservation of the species, and the protection of other birds that use these areas to rest, feed or reproduce. 


\section{Acknowledgements}

We are grateful to PPGEtno - UFRPE, the Garanhuns Academic Unit - UAG/UFRPE, the Zoology teaching laboratory (LABEZoo/UAG) and the ecology of winged vertebrates laboratory at UAG/UFRPE. We also thank the AGROFAMILIAR nucleus at UAG/UFRPE for projects financed by MCTI/MAPA/MDA/MEC/MPA/CNPq (announcement $\mathrm{N}^{\circ} 81 / 2013$ ) and MCTI/SECIS/MTE/ SENAES/CNPq (announcement $\mathrm{N}^{\circ}$ 89/2013), and to the Technological Vocational Center. We are also extremely grateful to Elcida Araújo, Suzeni Izidio and Elba Ferraz for the identification of the plant species.

\section{References}

AZEVEDO JÚNIOR, S.M., DIAS, M.M., LARRAZÁBAL, M.E., TELINO JÚNIOR, W.R., LYRA-NEVES, R.M. and FERNANDES, C.J.G., 2001. Recapturas e recuperações de aves migratórias no litoral de Pernambuco, Brasil. Ararajuba $=$ Brazilian Journal of Ornitology, vol. 9, no. 1, pp. 33-42.

AZEVEDO JÚNIOR, S.M., DIAS FILHO, M., LARRAZÁBAL, M.E.L. and FERNANDES, C.G., 2002. Capacidade de vôo de quatro espécies de Charadriiformes (Aves) capturadas em Pernambuco, Brasil. Revista Brasileira de Zoologia, vol. 19, no. 1, suppl. 1, pp. 183-190. http://dx.doi.org/10.1590/S010181752002000500013 .

AZEVEDO JÚNIOR, S.M., LARRAZÁBAL, M.E. and PENA, O. 2004. Aves aquáticas de ambientes antrópicos (salinas) do Rio Grande do Norte, Brasil. In: J.O. BRANCO, ed. Aves marinhas e insulares brasileiras: bioecologia e conservação. Itajaí: Conservação Internacional, pp. 255-266.

BERGSTROM, P.W., 1981a. Male incubation in Wilson's Plover (Charadrius wilsonia). The Auk. Journal of Ornithology, vol. 98, no. 4 , pp. $835-838$.

BERGSTROM, P.W., 1988b. Breeding biology of Wilson's Plovers. The Wilson Journal of Ornithology, vol. 100, no. 1, pp. 25-35.

BERGSTROM, P.W., 1988c. Breeding displays and vocalizations of Wilson's Plovers. The Wilson Journal of Ornithology, vol. 100 , no. 1, pp. 36-49.

BOETTCHER, R., PEEN, T., CROSS, R.R., TERWILLIGER, K.T. and BECK, R.A., 2007. An Overview of the status and distribution of Piping Plover in Virginia. Waterbirds, vol. 30, no. sp1, pp. 138151. http://dx.doi.org/10.1675/1524-4695(2007)030[0138:AOO TSA]2.0.CO;2.

BROWN, A.C. and SNYDER III, T.A., 2013. Status of breeding Wilson's Plovers (Charadrius Wilsonia) on St. Kitts, West Indies. The Journal of Caribbean Ornithology, vol. 26, no. 1, pp. 22-25.

BROWN, S., HICKEY, C., HARRINGTON, B. and GILL, R., 2001. The U.S. Shorebird Conservation Plan. 2nd ed. Manomet: Manomet Center for Conservation Sciences, $64 \mathrm{p}$.

BURGER, J. 1994. The effect of human disturbance on foraging behavior and habitat use in Piping Plover (Charadrius melodus). Estuaries, vol. 17, no. 3, pp. 695-70.

CABRAL, S.A.S., AZEVEDO JÚNIOR, S.M. and LARRAZÁBAL, M.E., 2006. Abundância sazonal de aves migratórias na Área de Proteção Integral de Piaçabuçu, Alagoas, Brasil. Revista Brasileira de Zoologia $=$ Zoologia. International Journal of Zoology, vol. 23 , no. 3 , pp. $865-869$.

CAIO, J., CARLOS, J.C. and VOISIN, J.F., 2011. Charadrius wilsonia brasiliensis Grantsau \& Lima, 2008, is a junior synonym of Charadrius crassirostris Spix, 1825. Bulletin of the British Ornithologists' Club, vol. 131, no. 3, pp. 165-170.

CORBAT, C.A. and BERGSTROM, P.W., 2000. Wilson's Plover (Charadrius wilsonia). In: P.G. RODEWALD, ed. The Birds of North America. Ithaca: Cornell Lab of Ornithology. 16 p.

DIÁRIO OFICIAL DA UNIÃO - DOU, 2014. [viewed 08 November 2014]. Available from: http://www.icmbio.gov.br/ portal/biodiversidade/fauna-brasileira/lista-de-especies/5558especie-5558.html.

DINIZ, C.G., GYZELY, N., MAGALHÃES, D.M., GUERREIRO, D., DOUGLAS, P., PEREIRA, C., PAULO, D.C., RENATO, F., FRANCISCO, D., WANDERLEY, C. and DINIZ, P., 2016. Cães domésticos predadores de ninho de batuíra bicuda (Charadrius wilsonia no nordeste brasileiro. Revista da Biologia $=$ Braziliam . Journal of Biology, vol. 16, no. 1, pp. 24-27.

ESKINAZI-LEÇA, E., MACEDO, S.J. and PASSAVANTE, J.Z.O., 1980. Estudo ecológico da Região de Itamaracá, Pernambuco - Brasil. V. Composição e Distribuição fazer microplâncton na Região do canal de Santa Cruz. Trabalhos Oceanograficos, vol. 15 , no. 2 , pp. $185-262$.

FLEMMING, S.P., CHIASSON, R.D., SMITH, P.C., AUSTINSMITH, P.J. and BANCROFT, R.P., 1988. Piping Plover status in Nova Scotia related to its reproductive and behavioral responses to human disturbance. Journal of Field Ornithology, vol. 59, no. 4, pp. 321-330.

GRANTSAU, R. and LIMA, P.C., 2008. Uma nova subespécie de Charadrius wilsonia (Aves, Charadriiformes) para o Brasil. Atualidades Ornitológicas, vol. 142, pp. 4-5.

LUNARDI, V.O. and MACEDO, R.H., 2010. First reprodutive record of Wilson's plover in Baía de Todos os Santos, Northeastern Brazil. The Wilson Journal of Ornithology, vol. 122, no. 4, pp. 788-791. http://dx.doi.org/10.1676/10-007.1.

MACEDO, S.J., MONTES, M.J.F. and LINS, I.C., 2000. Características abióticas da área. In: H.M. BARROS, E. ESKINAZI-LEÇA, S.J. MACEDO and T. LIMA, eds. Gerenciamento participativo de estuários e manguezais. Recife: Editora Universitária da Universidade Federal de Pernambuco. pp. 7-22.

ROCHA, G.C., 2016. Relação atmosfera e dinâmica sedimentar nas praias de Macapá e Maramar - Luis Correia - Piauí - Brasil. Caderno de Geografia, vol. 26, no. 2, pp. 197-213. http://dx.doi. org/10.5752/p.2318-2962.2016v26nesp2p300.

RODRIGUES, A.A.F., OREN, D.C. and LOPES, A.T.L., 1996. New data on breeding Wilson's Plovers Charadrius wilsonia in Brazil. Bulletin - Wader Study Group, vol. 81, no. x, pp. 80-81.

SHULTZ NETO, A., PEREIRA, S.F.T. and INTERAMINENSE, L.J.L. 1992. Novas ocorrências reprodutivas de Charadrius collaris e Charadrius wilsonia. In: Resumos do II Congresso Brasileiro de Ornitologia, 1992, Campo Grande. Mato Grosso do Sul, Brasil, p. R.83.

TELINO-JÚNIOR, W.R., AZEVEDO JUNIOR, S.M. and LYRANEVES, R.M., 2003. Censo de aves migratórias na Coroa do Avião, Igarassu, Pernambuco, Brasil. Revista Brasileira de Zoologia = Zoologia. International Journal of Zoology, vol. 20, no. 3, pp. 451-456. http://dx.doi.org/10.1590/S0101-81752003000300014. 
ZDRAVKOVIC, M.G., CORBAT, C.A. and BERGSTROM, P.W., 2018. Wilson's Plover (Charadrius wilsonia), version 1.1. In: P.G. RODEWALD, ed. The Birds of North America. Ithaca: Cornell Lab of Ornithology. https://doi.org/10.2173/bna.wilplo.01.1

WESTON, A.M. and ELGAR, M.A., 2007. Responses of incubating Hooded Plovers (Thinornis rubricollis) to disturbance.
Journal of Coastal Research, vol. 23, no. 3, pp. 569-576. http:// dx.doi.org/10.2112/04-0151.1.

WIERMA, P., 1996. Species accounts. Family Charadriidae (plovers). In: J.A. Hoyo, A. Elliott and J. Sargatal, eds. Handbook of the birds of the world. Barcelona: Lynx Edicions, vol. 3, pp. 384-443. 